\title{
NEW DISTRIBUTIONAL DATA ON BRYOPHYTES OF POLAND, 1
}

\author{
Piotr Górski, PaweŁ Pawlikowski, Monika Staniaszek-Kik, StanisŁaw Rosadziński, \\ Adam Stebel, Anna Rusińska, Robert Zubel, Marcin Wilhelm, Ewa Fudali, \\ Beata Cykowska-Marzencka, Lidia Przewoźnik
}

\author{
Editors of the column: Piotr Górski, AdAm Stebel, AnNa RusińsKa
}

B. Cykowska-Marzencka, Laboratory of Bryology, Institute of Botany Polish Academy of Sciences, Lubicz 46, 31-512 Kraków, Poland, e-mail: b.cykowska@botany.pl

E. Fudali, Department of Botany and Plant Ecology, Wrocław University of Environmental and Life Sciences, pl. Grunwaldzki 24 A, 50-652 Wrocław, Poland, e-mail: ewa.fudali@gmail.com

P. Górski, Department of Botany, Poznań University of Life Sciences, Wojska Polskiego 71 C, 60-625 Poznań, Poland, e-mail: peter@up.poznan.pl

P. Pawlikowski, Department of Plant Ecology and Environmental Conservation, Institute of Botany, Faculty of Biology, Biological and Chemical Research Centre, University of Warsaw, Żwirki i Wigury 101, 02-096 Warsaw, Poland, e-mail: p.pawlikowski@uw.edu.pl

L. Przewoźnik, Karkonosze National Park, Chałubińskiego 23, 58-570 Jelenia Góra, Poland, e-mail: lidia. przewoznik@kpnmab.pl

S. Rosadziński, Department of Plant Ecology and Environmental Protection, Faculty of Biology, Adam Mickiewicz University, Umultowska 89, 61-614 Poznań, Poland, e-mail: rosadzinskis@o2.pl

A. Rusińska, Natural History Collections, Adam Mickiewicz University, Umultowska 89, 61-614 Poznań, Poland, e-mail: annarus@amu.edu.pl

M. Staniaszek-Kik, Department of Geobotany and Plant Ecology, University of Łódź, Banacha 12/16, 90-237 Łódź, Poland, e-mail: kik@biol.uni.lodz.pl

A. Stebel, Department of Pharmaceutical Botany, Medical University of Silesia in Katowice, Ostrogórska 30, 41-200 Sosnowiec, Poland, e-mail: astebel@sum.edu.pl

M. Wilhelm, Department of Geobotany and Plant Taxonomy, University of Szczecin, Wąska 13, 71-415 Szczecin, Poland, e-mail: junin@univ.szczecin.pl

R. Zubel, Department of Botany and Mycology, Maria Curie-Skłodowska University, Akademicka 19, 20-033 Lublin, Poland, e-mail: robert.zubel@poczta.umcs.lublin.pl

(Received: March 20, 2014. Accepted: April 3, 2014)

1. Bucklandiella microcarpa (Hedw.) Bednarek-Ochyra \& Ochyra

Author: A. STEBEL

ATMOS Ge-31: S Poland, Pieniny Klippen Belt, Skalice Spiskie range, Małopolska Province, Trybsz, the Białka river valley, $49^{\circ} 25^{\prime} 16.1^{\prime \prime} \mathrm{N}, 20^{\circ} 7^{\prime} 21.39^{\prime \prime} \mathrm{E}$, granite boulder in Picea abies forest, alt. 640-642 m a.s.l., leg., det. A. Stebel, 11.06.2009 (SOSN, KRAM).

Bucklandiella microcarpa grows mainly on acid rocks in the mountains and on erratic in northern Poland. As a light-loving species, it occurs mainly at higher elevations in alpine and subalpine belts, but also frequently on appropriate habitats in forest belts, such as exposed rock outcrops and boulders among meadows. It is frequent or locally even common species in many ranges in the Carpathians (BEDNAREK-OCHYRA et al. 1990, BeDnarek-Ochyra 1995). Skalice Spiskie (= Pieniny Spiskie) belongs to bryological well known area of the Polish Carpathians (OchYra 1984, Ochyra \& CyкоWsKa 2008, Stebel 2010). Bucklandiella microcarpa was found on granite boulder in sparsely distributed Picea abies forest near the Białka river. The 
population was small, covering a dozen or so square centimeters and sterile. This is the new species to the Skalice Spiskie range.

\section{Calypogeia azurea Stotler \& Crotz}

Author: R. ZuBEL

ATMOS Fg-12: SE Poland, Roztocze region (Roztocze Środkowe), Lublin Province, Biłgoraj county, Józefów commune, Sopot river valley in the "Czartowe Pole" nature reserve, on humus and soil in Fraxino-Alnetum association, $50^{\circ} 26^{\prime} 25.7^{\prime \prime} \mathrm{N}, 23^{\circ} 05^{\prime} 22.1^{\prime \prime} \mathrm{E}$, leg., det. $\mathrm{R}$. Zubel, 8.06.2009 (LBL).

Calypogeia azurea is a liverwort widespread in the mountains. Lowland stations of the plant are restricted to NE Poland (Szweykowski 2006). This mountain species is known from scattered stations in Roztocze region (SzweyKowski 1957, KarczMarz 1967, Bloch \& KarCZMARZ 1973). Till now, C. azurea was not reported from the Sopot river valley (Mamczarz 1973). The new station extends the regional distributional data of this plant.

\section{Campylopus introflexus (Hedw.) Brid.}

Author: M. StANIASZEK-KIK

ATMOS Ed-24: Central Poland, the Bełchatowska Height (Wysoczyzna Bełchatowska), Łódź Province, Bełchatów county, $0.5 \mathrm{~km}$ NW from Trząs village, $51^{\circ}$ $17^{\prime} 30.7^{\prime \prime} \mathrm{N}, 19^{\circ} 12^{\prime} 50.4^{\prime \prime} \mathrm{E}$, peaty soil in the transitional mire, leg., det. M. Staniaszek-Kik, 2.10.2013 (LOD).

Campylopus introflexus is a neophytic moss in the bryoflora of Poland (OchYra 1983). Currently, it is known from numerous localities mostly in the western part of the country. In the area of Central Poland the species was found for the first time in 2006 in Smardzewice forest near Tomaszów Mazowiecki, Łódź Province (FudALI et al. 2009). Recently, other three localities have been found in the city of Łódź (Wolski 2011). The new finding of C. introflexus comes from the region of the Bełchatowska Height, where the species was recorded on peaty soil in a transitional mire. Patches of the moss were relatively small (30 $\mathrm{cm}^{2}$ ) and plants did not form sporophytes.

\section{Campylopus introflexus (Hedw.) Brid.}

\section{Author: P. GóRSKI}

ATMOS Ab-95: NW Poland, West Pomerania, West Pomerania Province, Koszalin county, Karnieszewice Forest Inspectorate, forest section 193d, $54^{\circ} 14^{\prime} 15.96 " \mathrm{~N}, 16^{\circ} 22^{\prime} 11.46^{\prime \prime} \mathrm{E}$, pine forest, near road, leg., det. P. Górski, 25.05.2012 (POZNB), forest section $168 \mathrm{~h}, 54^{\circ} 15^{\prime} 27.06^{\prime \prime} \mathrm{N}, 16^{\circ} 22.14 .4^{\prime \prime} \mathrm{E}$, dried peat, Vaccinio uliginosi-Pinetum, leg., det. P. Górski,
27.05.2012 (POZNB); ATMOS Ab-85: NW Poland, West Pomerania, West Pomerania Province, Koszalin county, Karnieszewice Forest Inspectorate, forest section 656d, 54 $19^{\prime} 13.14^{\prime \prime} \mathrm{N}, 16^{\circ} 16^{\prime} 2.04^{\prime \prime} \mathrm{E}$, leg., det. P. Górski, 5.07.2012 (POZNB), forest section 649a, $54^{\circ} 19^{\prime} 40.74^{\prime \prime} \mathrm{N}, 16^{\circ} 16^{\prime} 40.26^{\prime \prime} \mathrm{E}$, leg., det. $\mathrm{P}$. Górski, 5.07.2012 (POZNB); ATMOS Bb-05: NW Poland, West Pomerania, West Pomerania Province, Koszalin county, Karnieszewice Forest Inspectorate, forest section 271, 54 $12^{\circ} 42.66^{\prime \prime} \mathrm{N}, 1^{\circ} 19^{\prime} 57.9^{\prime \prime} \mathrm{E}$, leg., det. P. Górski, 26.05.2012 (POZNB); ATMOS Cb-67: W Poland, Wielkopolska region, Wielkopolska Province, Oborniki county, Bagno Chlebowo, $52^{\circ} 44^{\prime} 26.15^{\prime \prime} \mathrm{N}, 16^{\circ} 45^{\prime} 26.10^{\prime \prime} \mathrm{E}$, dried peat on the edge of degraded Vaccinio uliginosi-Pinetum, leg., det. P. Górski, 26.06.2011 (POZNB).

\section{Cephaloziella hampeana (Nees) Schiffn.}

Author: P. GóRSKI

ATMOS Db-18: W Poland, Wielkopolska region, Wielkopolska Province, Wielkopolski National Park, "Pod Dziadem" area of strict protection, decaying pine log, together with Nowellia curvifolia and Lophocolea heterophylla, leg. P. Urbański, R. Nowińska, 4.12.2009, det. P. Górski (POZNB).

Cephaloziella hampeana was recorded in Wielkopolska region over 50 years ago (SzWEYKOWSKI 1958). All newer data on this species from Poland are restricted to low elevations in the mountains and their foothills (SZWEYKOWSKI 2006).

5. Crossocalyx hellerianus (Nees ex Lindenb.) Meyl. (= Anastrophyllum hellerianum (Nees ex Lindenb.) R.M. Schust.)

\section{Authors: P. PAwLIKOwsKI, P. GóRsKI}

ATMOS Bf-03: NE Poland, the Borecka Primeval Forest (Puszcza Borecka), Warmia-Masuria Province, Giżycko county, Borki Forest Inspectorate, forest section $137,54^{\circ} 08^{\prime} 35.7^{\prime \prime} \mathrm{N}, 22^{\circ} 05^{\prime} 21.7^{\prime \prime} \mathrm{E}$, spruce forest on peat (Sphagno girgensohnii-Piceetum association), $1.5 \mathrm{~km} \mathrm{~N}$ of the "Borki" nature reserve, leg., det. P. Pawlikowski, 7.08.2013, conf. P. Górski (POZNB).

Crossocalyx hellerianus is a very rare epixylic liverwort, related to well preserved forests with a long ecological continuity (CIEŚLIŃSKI et al. 1996). In Poland it is known from the northern (mainly: north-eastern) part of the country as well as from the mountains (both Sudety Mts. and Carpathians). After 2000, the species was recorded in the Białowieża National Park (Klama 2002), the Świętokrzyski National Park (SteBeL et al. 2013), the Tatra Mts. (KLAma 2008, GóRSKI, unpublished) and the Augustowska Primeval Forest (Puszcza Augustowska) (Górski \& Pawlikowski, unpublished). 


\section{Distichium capillaceum (Hedw.) Bruch \& Schimp.}

Author: A. STEBeL

ATMOS Ge-30: S Poland, the Orawsko-Nowotarska Basin (Kotlina Orawsko-Nowotarska), Małopolska Province, Ludźmierz-Brzegi, between the Wielki Rogoźnik river and Szaflary-Ludźmierz road, $49^{\circ} 27^{\prime} 17.91^{\prime \prime} \mathrm{N}, 1^{\circ} 59^{\prime} 11.71 " \mathrm{E}$, shaded stone wall of viaduct, alt. $605 \mathrm{~m}$ a.s.l., leg., det. A. Stebel, 14.05.2009 (SOSN, KRAM).

Distichium capillaceum is a calciphilous moss, in Poland growing mainly in the Pieniny Klippen Belt (Ochyra 1984, Ochyra \& Stebel 2008, Stebel et al. 2010), Western Tatras (LisowsKi 1959) and in the Krakowsko-Częstochowska Upland (Wyżyna Krakowsko-Częstochowska) (FoJcıк 2011 a). It has tendencies to colonize athropogenic sites, mainly concrete walls. On this kind of habitat it was found in the Orawsko-Nowotarska Basin. Distichium capillaceum grew on stone wall of viaduct of closed down railway line Nowy Targ-Czarny Dunajec. The population was quite abundant and covered over one square meter. Many sporophytes were observed. Distichium capillaceum is the new species to the Orawsko-Nowotarska Basin.

\section{Ephemerum serratum var. angustifolium (Bruch \& Schimp.) Bruch \& Schimp.}

\section{Author: M. STANIASZEK-KIK}

ATMOS Gf-22: S Poland, Western Carpathians, Beskid Niski Mts., Podkarpacie Province, Krosno county, $0.5 \mathrm{~km} \mathrm{~S}$ from Nowa Wieś village, $49^{\circ} 31^{\prime} 6.31^{\prime \prime} \mathrm{N}, 21^{\circ} 41^{\prime} 30.69^{\prime \prime} \mathrm{E}$, on mineral soil in arable field, leg., det. M. Staniaszek-Kik, 20.08.2013 (LOD).

Ephemerum serratum var. angustifolium is a European temperate species (SмiтH 2004). It is a minute ephemeral taxon growing on damp non-calcareous soils in arable fields, stubble fields and grasslands (Szafran 1957, Stebel 2006). Until now, E. serratum has been recorded in the Beskid Niski Mts. only at few localities (Karczmarz 1987, Stebel \& Ochyra 2000), but unfortunately without any details about the varieties. The species has been placed in a rare category (R) on the Red list of threatened mosses in Poland (ŻARNOwIEC et al. 2004).

8. Fuscocephaloziopsis catenulata (Huebener) Váňa et L. Söderstr. (= Cephalozia catenulata (Huebener) Lindb.)

Authors: P. GóRsKI, P. PAwLIKOwsKI

ATMOS Bf-03: NE Poland, the Borecka Primeval Forest, Warmia-Masuria Province, Giżycko coun- ty, Borki Forest Inspectorate, forest section 137, $54^{\circ} 08^{\prime} 35.7^{\prime \prime} \mathrm{N}, 22^{\circ} 05^{\prime} 21.7^{\prime \prime} \mathrm{E}$, spruce forest on peat (Sphagno girgensohnii-Piceetum association), $1.5 \mathrm{~km}$ $\mathrm{N}$ of the "Borki" nature reserve, leg. P. Pawlikowski, 7.08.2013, det. P. Górski (POZNB).

Fuscocephaloziopsis catenulata is a rare liverwort bound to well preserved forests with a long ecological continuity (CIEŚLIŃSKI et al. 1996). In Poland it occurs in the northern part of the country and virtually in all mountain ranges (SzWEYKOWSKI 1958, 2006). After 2000 the species was collected in the Białowieża National Park (Klama 2002), the Augustowska Primeval Forest (GórsKi \& PAWLIKOWsKI, unpublished), Roztocze National Park (GóRSKI, unpublished), Świętokrzyski National Park (Stebel et al. 2013), Tatra Mts. (KLAMA 2008, GóRsKI, unpblished) and West Pomerania (GóRski 2013).

9. Fuscocephaloziopsis loitlesbergeri (Schiffn.) Váňa et L. Söderstr. (= Cephalozia loitlesbergeri Schiffn.)

Author: P. GóRSKI

ATMOS Ac-86: N Poland, Pomorze Gdańskie, Pomerania Province, Kartuzy county, peat-bog $S$ from Mirachowo, leg. F. Krawiec as Cephalozia connivens, 28.08.1936, det. ?, conf. P. Górski (POZW 3606).

Fuscocephaloziopsis loitlesbergeri is an extremely rare species, threatened with extinction in the majority of Central-European countries. In Poland, it is considered rare (R category; KLAmA 2006). The new locality is the seventh site of this species in the country. So far, F. loitlesbergeri has been reported from Polish lowlands (four localities), Western Carpathians (the Tatra Mts., one) and Sudety Mts. (one) (Müller 1912-1916, LiLIENFELdówna 1914, WiśNIEWSKi \& RejMENT 1935, Dietzow 1938, Szweykowski 1953, GórSKI \& PAWLIKOWsKI, unpublished). The locality from the Tatra Mts. (Lilienfeldówna 1914) still exsists at Toporowy Staw Wyżni lake (GóRSKI, unpublished).

\section{Hedwigia ciliata (Hedw.) P. Beauv.}

\section{Author: R. ZuBEL}

ATMOS: Ef-34: SE Poland, the Lubelska Upland Chodelska Basin (Wyżyna Lubelska - Kotlina Chodelska), Lublin Province, Opole county, Karczmiska commune, the Wolicki Forest (Las Wolicki), $3 \mathrm{~km}$ on $\mathrm{S}$ of Poniatowa town, $51^{\circ} 11^{\prime} 35.0^{\prime \prime} \mathrm{N}, 2^{\circ} 01^{\prime} 32.6^{\prime \prime} \mathrm{E}$, on erratic boulder in oak-pine forest, leg., det. R. Zubel, 22.06.2006 (LBL); ATMOS Eg-91: SE Poland, Lublin Province, Zamojski county, Zwierzyniec commune, the Roztocze National Park, surroundings of the Foresters Memorial, forest section 197, $50^{\circ} 36^{\prime} 00.0^{\prime \prime} \mathrm{N}$, $22^{\circ} 57^{\prime} 55.8^{\prime \prime} \mathrm{E}$; granite boulder (memorial's element) beside the Bukowa Góra didactic path, leg., det. R. Zubel, 15.07.2010 (LBL). 
Hedwigia ciliata in the Lublin Province is known from only three documented stations (KARCZMARZ 1960, OchYra et al. 1988 c). The presented data extend the distribution of $H$. ciliata at the regional scale. This epilithic species is connected with non-calcareous rocks and stones e.g. erratic boulders. For that reason the occurrence of the species in $\mathrm{W}$ and NW part of the region has a natural character, whereas the station located in the Roztocze National Park has probably an anthropogenic origin (introduced together with the granite elements of the memorial).

\section{Helodium blandowii (F. Weber \& D. Mohr) Warnst.}

\section{Author: P. PAWLIKOWSKI}

ATMOS Cd-29: Masovia Province, Żuromin county, Kluczbork-Osada commune, Gościszka, $53^{\circ} 06^{\prime} 36.9^{\prime \prime} \mathrm{N}, 20^{\circ} 00^{\prime} 42.0^{\prime \prime} \mathrm{E}$, willow-birch shrubs in old, overgrown peat-cuttings in moderately degraded, soligenous rich fen in the Przylepnica river valley, W of the river and $0.5 \mathrm{~km} \mathrm{SE}$ of the Gościszka village, single clump and scattered shoots growing along with Calliergonella cuspidata, Aulacomnium palustre, Plagiomnium ellipticum, Climacium dendroides and Sphagnum teres, leg., det. P. Pawlikowski, 19.11.2013 (KRAM); ATMOS Cf-73: Masovia Province, Ostrów Mazowiecka county, Małkinia Górna commune, Poniatowo village, $52^{\circ} 38^{\prime} 49.7^{\prime \prime} \mathrm{N}, 22^{\circ} 02^{\prime} 53.7^{\prime \prime} \mathrm{E}$, willow-birch shrubs in old, overgrown peat-cuttings in degraded, soligenous rich fen in the Treblinka river valley, $\mathrm{S}$ of the river and $1 \mathrm{~km} \mathrm{NE}$ of the Poniatowo village, small and scattered patches growing along with Climacium dendroides, Calliergonella cuspidata, Aulacomnium palustre and Sphagnum fimbriatum, leg., det. P. Pawlikowski, 17.12.2013 (KRAM).

Helodium blandowii is a species growing in minerotrophic fens, not uncommonly found in the post-glacial landscape of $\mathrm{N}$ and NW Poland, as well as in the uplands of S Poland (Ochyra et al. 1988 a), considered vulnerable in Poland (V category ŻARNOWIEC et al. 2004). In the Masovia Province the species has been recorded in six localities: 1) Bagno Całowanie peatland, 2) former "Pociecha" nature reserve in the Kampinoski National Park, 3) Kuzie village, by the border with Podlasie Province, 4) Pakosław peatland, 5) "Torfowisko Serafin" nature reserve, 6) Przylepnica river valley by the Chojnowo village (OchYra et al. 1988 a, JARZOMBKOWSKI \& Kozub 2011). Only the latter three populations (4-6) have been confirmed recently, and most (or all) of the remaining ones (1-3) are most probably extinct (PawlikowsKI, unpublished).
12. Nowellia curvifolia (Dicks.) Mitt.

\section{Author: B. CyKowsKa-MarzencKA}

ATMOS Gf-20: SE Poland, the Beskid Niski Mts., Podkarpacie Province, Jasło county, the Magurski National Park, Mt Uherec, in forest between Nieznajowa and Rostajne villages, $49^{\circ} 30^{\prime} 00.0^{\prime \prime} \mathrm{N}$, E212ㄴ $40.6^{\prime \prime E}$, alt. $486 \mathrm{~m}$ a.s.1., slope $15^{\circ}$, exposition SE, on fir log in Dentario glandulosae-Fagetum association, leg., det. B. Cykowska-Marzencka, 20.07.2013 (KRAM); Gf-21: SE Poland, Beskid Niski Mts., Podkarpacie Province, Jasło county, Magurski National Park, "Zimna Woda" area of strict protection, above Przykry Horb forest, $49^{\circ} 28^{\prime} 12.3^{\prime \prime} \mathrm{N}$, $21^{\circ} 31^{\prime} 14.2^{\prime \prime E}$, alt. $632 \mathrm{~m}$ a.s.l., slope $15^{\circ}$, exposition E, on spruce log in Dentario glandulosae-Fagetum association, leg., det. B. Cykowska-Marzencka, 21.07.2013 (KRAM); Gf-30: SE Poland, Beskid Niski Mts., Podkarpacie Province, Jasło county, Magurski National Park, Przylaszowski Forest, $1 \mathrm{~km} \mathrm{~N}$ of Grab village, $49^{\circ} 26^{\prime} 55.5^{\prime \prime} \mathrm{N}, 21^{\circ} 27^{\prime} 11.1^{\prime \prime E}$, alt. $521 \mathrm{~m}$ a.s.l., on spruce stump in spruce forest, leg., det. B. Cykowska-Marzencka, 22.07.2013 (KRAM).

Nowellia curvifolia is a lignicolous species connected with coniferous wood. It has a centre of occurrence in northern Poland, is very rare in central part of the country and not frequent in the mountains (SZWEYKOWSKI 1969, 2006, GóRSKI 2010, 2013). So far, the species has not been reported from the Beskid Niski Mts. (MierZeńsKa 2000) and three localities published here are first in these mountains and first in the Magurski National Park.

\section{Odontoschisma denudatum (Mart.) Dumort.}

Author: R. Zubel

ATMOS Fg-01: SE Poland, Roztocze region, Lublin Province, Biłgoraj county, Józefów commune, the Roztocze National Park (S part), Florianka protective district, $1 \mathrm{~km}$ NE of Górecko Stare village, forest section $331,50^{\circ} 31^{\prime} 54.5^{\prime \prime} \mathrm{N}, 23^{\circ} 00^{\prime} 29.2^{\prime \prime} \mathrm{E}$, decaying pine log in Vaccinio uliginosi-Pinetum association, leg., det. R. Zubel, 29.08.2011 (LBL).

This liverwort, beside the Polish Carpathians where it does not occur, is rather common in the NE and SW Poland (SzWEYKowski 2006). The species has also scattered localities in the NW part of the country (GóRski 2010, 2013). The distribution of this species in the SE Poland needs further, more detailed studies. It is possible to find the next localities of O. denudatum, especially in the Roztocze region, on the grounds of the abundant occurrence of suitable habitats and substrata for this species. 
14. Orthocaulis atlanticus (Kaal.) H. Buch (= Barbilophozia atlantica (Kaal.) Müll. Frib.)

\section{Authors: P. GóRskI, L. PrzewoźNIK}

ATMOS Ea-78: SW Poland, the Karkonosze Mts., $50^{\circ} 46^{\prime} 39.78^{\prime \prime N}, 15^{\circ} 31 ' 35.82 " E$, near Mt Sokolnik, alpine grassland Carici bigelowii-Nardetum, alt. $1400 \mathrm{~m}$ a.s.l., leg. L. Przewoźnik, 3.08.2013, det. P. Górski, conf. J. Váňa (POZNB).

Orthocaulis atlanticus is a high-alpine species reported in Poland so far only in the Tatra Mts. (SZWEYKOWSKI 1956, 1960, 1967, 2006, BALCERKIEWICZ 1984, Szweykowski \& BuczkowsKa 2000, СүкоwsKa 2006, 2011, GórsKI, unpublished). Including data from Slovakian part of this massive (see SMARDA 1961, VáŇa 1969, Peciar 1978, Duda 1983, Duda \& VÁŇA 1984), O. atlanticus can be found in the Tatra Mts. in 29 localities (26 in the Polish part), in altitude range between $1650 \mathrm{~m}$ and $2220 \mathrm{~m}$ a.s.l. The presented new site of this species is the first one in the Sudety Mts., found in the Karkonosze Mts. Orthocaulis atlanticus grew in a dense alpine grassland with domination of Nardus stricta with the following floristic composition: Nardus stricta 5, Carex bigelowii subsp. rigida 3, Deschampsia flexuosa 1, Anthoxanthum alpinum r, Orthocaulis atlanticus r, Plagiothecium curvifolium r, Pleurozium schreberi r, Polytrichastrum formosum r, and Calliergon stramineum r. It should be noted; however, that $O$. atlanticus was recorded in three localities in the Czech part of the Karkonosze Mts. by J. Duda, based on the specimens collected by V. Schiffner and J. Šmarda (see Duda in DudA \& VÁÑa 1984).

\section{Pallavicinia lyellii (Hook.) Carruth.}

\section{Author: S. RosADZIŃSKI}

ATMOS Ad-63: W Poland, the Gubińskie Height (Wzniesienia Gubińskie), Lubuskie Province, Żary county, Brody commune, $1 \mathrm{~km}$ NW of the Suchodó1 village, $51^{\circ} 47^{\prime} 55.14^{\prime \prime} \mathrm{N}, 14^{\circ} 43^{\prime} 6.48^{\prime \prime} \mathrm{E}$, in the patches of Sphagno-Alnetum and Vaccinio uliginosi-Betuletum pubescentis associations, on the acidic Sphagnum peat, very abundant but scattered population in the form of small clusters on flat cushions of Sphagnum palustre and $S$. fimbriatum and in larger ones on the eroded peat moss hummocks where the liverwort was growing with Mnium hornum, Pohlia nutans and Calypogeia fissa $(\mathrm{pH}$ 4.0 and $190 \mu \mathrm{S} \mathrm{cm}^{-1}$ - mean values of reaction and conductivity for soil solution), and very rarely on decaying alder logs, in the complex of topogenic poor fens and swamp forests in the basin of the Suchodól lake, leg., det. S. Rosadziński, 11.09.2012 (POZG); ATMOS Ad-64: W Poland, the Gubińskie Height, Lubuskie Province, Żary county, Lubsko commune, $2 \mathrm{~km} \mathrm{NW}$ of the Osiek village, $51^{\circ} 50^{\prime} 9.35^{\prime \prime} \mathrm{N}, 14^{\circ} 53^{\prime} 56.12^{\prime \prime} \mathrm{E}$, in patches of Sphagno-Alnetum association, single thalli among the stems of Sphagnum palustre in the upper part of hummock formed by peat mosses $(\mathrm{pH} 3.8$ and 240 $\mu \mathrm{S} \mathrm{cm}{ }^{-1}$ - values of reaction and conductivity for soil solution) at the base of alder, leg., det. S. Rosadziński, 7.08.2010 (POZG); ATMOS Ad-74: W Poland, the Zasiecka Basin (Kotlina Zasiecka), Lubuskie Province, Żary county, Brody commune, $1.8 \mathrm{~km}$ NW of the Proszów village, $51^{\circ} 45^{\prime} 3.98^{\prime \prime} \mathrm{N}, 14^{\circ} 50^{\prime} 22.75^{\prime \prime} \mathrm{E}$, Sphagno-Alnetum association, acidic peaty muck substrate, at the base of Alnus glutinosa, leg. S. Rosadziński, 27.07.2009, det. A. Rusińska (POZG).

Pallavicinia lyellii has a suboceanic geographical range (DüLl 1983) and is threatened in Europe (SCHUMACKer \& Martiny 1995). In Poland it is considered as endangered (E category; Klama 2006). Nowadays it is known from about 7-10 localities in Poland (KoŁa 1969, MierzeńsKa 2001, Stebel 2008, RosadzińsKi \& RusińsKa 2010, GóRsKi 2013, POZG unpublished). The species is considered as differential of a local (subatlantic) form of Sphagno-Alnetum association in the western Poland.

\section{Riccia cavernosa Hoffm.}

\section{Author: R. ZuBEL}

ATMOS Eg-12: E Poland, the Łęczyńsko-Włodawska Plain (Równina Łęczyńsko-Włodawska), Lublin Province, Chełm county, Wierzbica commune, 4 $\mathrm{km}$ on N of Wólka Tarnowska village, $51^{\circ} 20^{\prime} 41.7^{\prime \prime} \mathrm{N}$, $23^{\circ} 17^{\prime} 36.9^{\prime \prime} \mathrm{E}$, peaty soil, pasture on the edge of alder forest, leg., det. R. Zubel, 24.07.2013 (LBL).

It is the first station of Riccia cavernosa in the SE Poland. The species seems to be more frequent in other parts of the country (e.g. JASNOWSKA et al. 1993, GÓRSKI 2010) by reason of that all published Polish stations of $R$. crystallina probably belong to the $R$. cavernosa (SzWEYKOWSKI 2006).

\section{Sciuro-hypnum plumosum (Hedw.) Ignatov \& Huttunen}

Author: A. STEBEL

ATMOS Fd-66: S Poland, the Kraków-Częstochowa Upland (Wyżyna Krakowsko-Częstochowska), the Tenczyński Hummock (Garb Tenczyński), Małopolska Province, Alwernia, 50³'59.35"N, 19³2'11.62"E, melaphyre outcrops close to stream in ravine near the monastery, leg., det. A. Stebel, 7.08.2013 (SOSN, KRAM).

Sciuro-hypnum plumosum is a montane species, growing for example quite frequent in the Western Beskidy Mts. (Stebel 2006). Outside the mountains it occurs on scattered localities, mainly in the uplands in southern Poland (Kuc 1964, Stebel 2000, 2009 a, FojciK \& Stebel 2001). The moss flora of the Kraków-Częstochowa Upland belongs to the best known in Poland (Fојсік 2011 a, b). New locality of 
S. plumosum is located in the ravine $\mathrm{E}$ of the monastery. The population was sterile but quite abundant, and covered over one square meter. This species grew in few patches on melaphyre in and close to a small stream. This is the fourth locality of S. plumosum in the Krakowsko-Częstochowska Upland, while one of the earlier ones reported (HEREŹNIAK et al. 1973) seems to be doubtful (Fојсік 2011 a).

\section{Sphagnum tenellum (Brid.) Pers. ex Brid.}

\section{Author: M. WiLHeLM}

ATMOS Bb-47: NW Poland, West Pomerania, West Pomerania Province, Szczecinek county, the "Bagno Kusowo" nature reserve, Rhynchosporetum albae moist depressions in the peat-bog (in the south, the regenerating cutover peatland and the northern, never exploited part of the bog), forming a mosaic of micro-habitats of phytocenoses Sphagnetum magellanici and Eriophoro-Sphagnetum recurvi associations, species growing mostly accompanied by Sphagnum cuspidatum and Drosera rotundifolia, sometimes with Sphagnum rubellum, leg., det. M. Wilhelm, 14.07.2005 (SZUB).

Sphagnum tenellum is a rare sphagnum moss species occurring on ombrotrophic to weakly minerotrophic bogs, as small loose cushions between hollows and hummocks. The species is considered as vulnerable in Poland (V category; ŻARNOWIEC et. al. 2004) and has been recorded from several stations from the whole area of the country: bog near Niewiadowo in the Gowienica river valley (JASNOWSKI 1962), peat-bog between Trzebielino and Cetyń (JASNOWSKA \& JASNOWSKI 1983), "Torfowisko Pobłockie" nature reserve (JASNOWSKI 1990), county Bytów (ATMOS: Bc-12, Bc-21, Bc-22; LIsowsKI et. al. 2000), the Orawsko-Nowotarska Basin (Kotlina Orawsko-Nowotarska) (Koczur 2006) and the Sudety Mts. (WojtuŃ 2006).

\section{Splachnum ampullaceum Hedw.}

\section{Author: M. STANIASZEK-KIK}

ATMOS Bf-19: NE Poland, the Litewskie Lakeland (Pojezierze Litewskie), Podlasie Province, Suwałki county, Wigry National Park, Czarna Hańcza valley, $54^{\circ} 2^{\prime} 45.98 " \mathrm{~N}, 23^{\circ} 2^{\prime} 31.36^{\prime \prime} \mathrm{E}$, on excrements of herbivorous mammals on peat-bog, leg., det. M. Staniaszek-Kik, 4.05.2002 (LOD), 29.09.2013 (LOD).

Splachnum ampullaceum is one of the most frequently recorded coprophilous species of mosses in Poland. It is known from the localities throughout the whole country, mainly in the lowland regions, particularly in the northern areas. A large part of the known records of this species comes from the nineteenth and early twentieth century. Until now, only three localities have been identified in the Litewskie
Lakeland (SzmajDA et al. 1991). The occurrence of $S$. ampullaceum has not been confirmed in the Wigry National Park during briological investigation in 2008 -2009 (WierzCholsKa et al. 2010). The new locality presented in this study is the second one known from the Wschodniosuwalskie Lakeland (Pojezierze Wschodniosuwalskie), which is a part of the Litewskie Lakeland. This species has been placed on the Red list of threatened mosses in Poland, in the vulnerable (V category; ŻARNOWIEC et al. 2004).

\section{Syntrichia laevipila Brid.}

\section{Author: A. RusiŃSKA}

ATMOS Db-09: W Poland, Wielkopolska region, Wielkopolska Province, the city of Poznan (Poznań-Antoninek), W side of Sarnia Street, bark of Populus nigra 'Italica' in lower part of the trunk, population area ca $3 \mathrm{~cm}^{2}$, leg., det. A. Rusińska 8456, 9.03.2012 (POZG).

Presently this oceanic-submediterranean species (DülL 1984) is one of the most rare epiphytes of deciduous trees in Poland. It is strictly protected and has been placed on the Red-list of threatened mosses with I category (ŻARNOwIEC et al. 2004). Syntrichia laevipila grows on the bark of roadside trees - mainly on poplars, sometimes willows, apple trees, lindens or ashes. The species is known nowadays mainly from historical data. It was recorded in Pomerania by e.g.: KLingGraefF (1893), Winkelmann (1893), WarnSTORF (1906), and contemporary by FudaLi (1995) in Szczecin. In the bryological literature there are several localities of S. laevipila in southern Poland, e.g.: the Lubelska Upland (Karczmarz 1960), the Nidziańska Basin (WaCEAWSKA 1964), the Sandomiersko-Opatowska Upland (Kuc 1959, Ochyra 1976), some of them however are probably incorrectly determinated (A. Stebel, personal information). The species was also collected in the Ełk Lake District, Masurian Lakeland (OCHYra \& BEDNAREK-OChYRA 1990).

In Wielkopolska S. laevipila was found only once in Northern Wieleń (Koppe 1929). The specimens found in Poznan have typical traits of habitus, i.e. plants grow in small cushions, and leaves have very long, smooth or obscurely denticulate hyaline points.

\section{Syntrichia latifolia (Bruch ex Hartm.) Huebener (= Tortula latifolia Bruch ex Hartm.)}

\section{Author: E. FudALI}

ATMOS Eb-48: SW Poland, the Śląska Lowland (Nizina Śląska), Lower Silesia Province, the city of Wrocław, housing estate Szczepin (formerly Stare Miasto district), green square next to the car park at Inowrocławska 2 street, $51^{\circ} 6^{\prime} 49.32 \mathrm{~N}, 17^{\circ} 0^{\prime} 497.1^{\prime \prime} \mathrm{E}$, bark of poplar Populus nigra L. (about 40 years old) at 
hight $0.3 \mathrm{~m}$ above the ground level $\mathrm{NE}(\mathrm{pH}$ of bark = 7,2), leg., det. E. Fudali, 1.05.2012 (KRAM).

Syntrichia latifolia is a rare epiphytic moss species occurring on bark of deciduous trees (mainly wayside trees). As many bryo-epiphytes it shows tendency to colonize rock-like anthropogenic sites as concrete walls and lining of banks and most of the recent reports refers to that kind of habitats. The species was reported from singular stations from the whole area of the country but majority of them are situated in southern part: the Kaczawskie Mts. (WILCZYŃSKA 1974), the Racibórz Basin (Kotlina Raciborska) (Stebel 2005), Śląsk Opolski (Stebel 2008), the Śląska Upland (Wyżyna Śląska) (Stebel 1997), the Kraków-Częstochowa Upland (FoנcIK 2011 b), Carpathians foothills (Stebel 2009 b). It was also recorded in towns (Fudali 1998).

\section{Thamnobryum alopecurum (Hedw.) Gangulee}

Author: R. ZuBeL

ATMOS Fg-01: SE Poland, Roztocze region, Lublin Province, Biłgoraj county, Józefów commune, the Roztocze National Park (S part), Florianka protective district, SSW slopes of the Świstkowa Góra hill (312 $\mathrm{m}$ a.s.l.), group of Miocene limestone outcrops called "Płaczący Kamień", forest section 317, 50³2'31.7"N, $22^{\circ} 59 ' 25.2^{\prime \prime} \mathrm{E}$, on moist limestone in mixed forest, leg., det. R. Zubel, 27.04.2013 (LBL).

Thamnobryum alopecurum is widely distributed in the Sudety Mts. and the Carpathians and on the adjacent uplands. The plant has dispersed localities in the northern part of the country, but it is exceedingly rare in the Central and East Poland. Although the species is worldwide and has a rather great number of localities, it cannot be considered as a common (Bednarek-Ochyra et al. 1994). The new finding of T. alopecurum is the first one in the Roztocze National Park and the second in the region, where the species was only once recorded over 50 years ago form the "Góra Kamień" nature reserve near Stanisławów (Kuc 1958, 1963).

\section{Tomentypnum nitens (Hedw.) Loeske}

\section{Author: P. PAwLIKOWSKI}

ATMOS Df-81: Masovia Province, Garwolin county, Maciejowice commune, $1 \mathrm{~km} \mathrm{~S}$ of the Oronne village, the "Torfy Orońskie" nature reserve, $51^{\circ} 41^{\prime} 37.0^{\prime \prime} \mathrm{N}$, $21^{\circ} 36$ '37.7"E, calcareous rich fen overgrowing with shrubs and reed, developed at the bottom of the margin of the Vistula river valley, small, scattered patches growing along with Limprichtia cossonii, Calliergonella cuspidata, Campylium stellatum, Plagiomnium elatum and Bryum pseudotriquetrum, leg., det. P. Pawlikowski, 17.12.2011 (KRAM); ATMOS Ce-20: Masovia Prov- ince, Żuromin county, Kluczbork-Osada commune, Chojnowo, $53^{\circ} 06^{\prime} 03.6^{\prime \prime} \mathrm{N}, 20^{\circ} 03^{\prime} 48.5^{\prime \prime} \mathrm{E}$, willow-birch shrubs in old, overgrown peat-cuttings in moderately degraded, soligenous rich fen in the Przylepnica river valley, E of the river and $1 \mathrm{~km}$ SE of the Chojnowo village, small, scattered patches growing along with Aulacomnium palustre, Calliergonella cuspidata, Climacium dendroides, Sphagnum teres, S. palustre, S. warnstorfii, Helodium blandowii and Plagiomnium ellipticum, leg., det. P. Pawlikowski, 19.11.2013 (KRAM).

Tomentypnum nitens is a species related to rich fens, known from quite numerous localities in the post-glacial landscape of N and NW Poland, as well as in the uplands of S Poland (Ochyra et al. 1988 b), considered vulnerable in Poland ( $\mathrm{V}$ category; ŻARNOWIEC et al. 2004). In the Masovia Province the species has been recorded in 10 localities: 1-5) five sites in the Gostynin-Włocławek Forest, 6) Bagno Całowanie peatland, 7) by Łubiec village in the Kampinoski National Park, 8) Natolin in Warsaw, 9) Pakosław peatland and 10) "Torfowisko Serafin" nature reserve (OchYRA et al. 1988 b, JARZOMBKOWSKI \& Kozub 2011). Only three of the above populations (9-10 and by Nałęcin settlement in the Gostynin-Włocławek Forest) have been confirmed recently. The majority of the remaining localities are certainly extinct (PAwLIKowsKI, unpublished).

\section{Trichocolea tomentella (Ehrh.) Dumort.}

\section{Author: B. CYкowsKa-MarzencKA}

ATMOS Gf-21: SE Poland, the Beskid Niski Mts., Podkarpacie Province, Jasło county, the Magurski National Park, Mt Kamień, "Kamień" area of strict protection, $1 \mathrm{~km}$ NW of Myscowa village, $49^{\circ} 32^{\prime} 24.0^{\prime \prime} \mathrm{N}$, $21^{\circ} 32^{\prime} 14.5^{\prime \prime E}$, alt. $404 \mathrm{~m}$ a.s.l., slope $15^{\circ}$, exposition $\mathrm{E}$, on log submerge in stream in bich forest, leg., det. B. Cykowska-Marzencka, 19.07.2013 (KRAM).

Trichocolea tomentella is a lowland and foothills species, very rare in the mountains (SZWEYKOWSKI 1966, 2006). The species was found for the first time in the Magurski National Park on only one locality and this is the second station of the species in all the area of the Beskid Niski Mts. (Szweykowski 1966, MierzeńSKA 2000). Despite the testing carried out throughout the park, the species has not been found on more positions.

Acknowledgements. The contribution by $\mathrm{B}$. Cykowska-Marzencka has been financially supported by the Polish Ministry of Science and Higher Education through grant no. NN 303572038.

\section{REFERENCES}

BALCERKIEWICZ S. (1984): Roślinność wysokogórska Doliny Pięciu Stawów Polskich w Tatrach i jej 
Piotr Górski, Adam Stebel, Anna Rusińska

przemiany antropogeniczne. Uniwersytet im. Adama Mickiewicza, Seria Biologia 25: 1-191.

BednareK-Ochyra H. (1995): Rodzaj Racomitrium (Musci, Grimmiaceae) w Polsce: taksonomia, ekologia i fitogeografia. Fragmeta Floristica et Geobotanica Polonica 2: 3-307.

Bednarek-Ochyra H., Ochyra R., Szmajda P. (1990): M. 270. Racomitrium microcarpon (Hedw.) Brid. In: R. Ochyra, P. Szmajda (eds). Atlas of the geographical distribution of spore plants in Poland. Vol. 6. Series. V. Mosses (Musci). W. Szafer Institute of Botany, Polish Academy of Sciences and Adam Mickiewicz University, Kraków-Poznań: 25-30.

BednareK-Ochyra H., Ochyra R., Szmajda P. (1994): M. 455. Thamnobryum alopecurum (Hedw.) Gang. In: R. Ochyra, P. Szmajda (eds). Atlas of the geographical distribution of spore plants in Poland. Vol. 9. Series. V. Mosses (Musci). W. Szafer Institute of Botany, Polish Academy of Sciences and Adam Mickiewicz University, Kraków-Poznań: 27-35.

Bloch M., Karczmarz K. (1973): Zapiski briologiczne z Lubelszczyzny. Część III. Fragmenta Floristica et Geobotanica 19(4): 461-465.

Cieśliński S., Czyżėwska K., Faliński J.B., Klama H., MuŁenko W., Żarnowiec J. (1996): Relicts of the primeval (virgin) forest. Relict phenomena. In: J.B. Faliński, W. Mułenko (eds). Cryptogamous plants in the forest communities of Białowieża National Park. Functional groups analysis and general synthesis (Project Crypto 3). Phytocoenosis 8 (N. S.), Archivum Geobotanicum 6: 197-216.

CyкоwskA B. (2006): Kępy torfowcowo-płonnikowe w Tatrach Polskich - godne uwagi siedlisko dla wątrobowców. In: Z. Mirek, B. Godzik (eds). Tatrzański Park Narodowy na tle innych górskich terenów chronionych. Tatrzański Park Narodowy and Polskie Towarzystwo Przyjaciół Nauk o Ziemi Oddział w Krakowie, Zakopane-Kraków: 63-66.

Cyкоwska B. (2011): Bryophytes of Sphagnum-Polytrichum hummocks in the Polish Tatra Mountains. In: A. Stebel, R. Ochyra (eds). Chorological studies on Polish Carpathian bryophytes. Sorus, Poznań: 233-259.

Dietzow L. (1938): Die Moose Altpreussens und ihre Standorte. Jahresbericht des Preussichen Botanischen Vereins (Königsberg).

DudA J. (1983): Barbilophozia atlantica in der Tschechoslovakei (Hepaticae). Preslia 55(3): 265-267.

DudA J., VÁŇA J. (1984): Rozšíření játrovek v Československu - XLI. Časopis Slezského Muzea, Series A, Opava 33: 217-232.

Düll R. (1983): Distribution of the European and Macronesian liverworts (Hepaticophytina). Bryologische Beiträge 2: 1-115.

DüLl R. (1984): Distribution of the European and Macronesian mosses (Bryophytina). Part I. Bryologische Beiträge 4: 1-109.
Fojcik B. (2011 a): Distribution atlas of mosses of the Cracow-Częstochowa Upland. Centrum Dziedzictwa Przyrody Górnego Sląska, Katowice.

FoJcıK B. (2011 b): Mchy Wyżyny Krakowsko-Częstochowskiej w obliczu antropogenicznych przemian szaty roślinnej. Prace Naukowe Uniwersytetu Śląskiego w Katowicach 2800.

FojciK B., Stebel A. (2001): Struktura ekologiczna i przestrzenna brioflory miasta Katowice. Materiały Opracowania Centrum Dziedzictwa Przyrody Górnego Śląska w Katowicach 5: 1-128.

FudALI E. (1995): Changes in the bryoflora of urban areas - a case study of Leśne Wzgórze in Szczecin (NW Poland). Fragmenta Floristica et Geobotanica 40(1): 311-321.

Fudali E. (1998): Investigations of bryophytes in Polish towns - a review of the bryological research and data. Fragmenta Floristica et Geobotanica 43(1): 77-101.

Fudali E., SzCZEPAŃSKi M., RusińsKa H., RosadzińsKi S., Wolski G. (2009): The current distribution in Poland of some European neophytic bryophytes with supposed invasive tendencies. Acta Societatis Botanicorum Poloniae 78(1): 73-80.

GóRsKI P. (2010): A contribution to the liverwort flora of the Drawsko lake district (Western Pomerania, Poland). Roczniki Akademii Rolniczej w Poznaniu 389, Botanika-Steciana 14: 19-26.

GóRsKi P. (2013): Wątrobowce (Marchantiophyta) Leśnego Kompleksu Promocyjnego „Lasy Środkowopomorskie" (Pomorze Zachodnie). PGL Lasy Państwe Nadleśnictwo Karnieszewice, Wydawnictwo Uniwersytetu Przyrodniczego w Poznaniu, Sianów-Poznań.

Hereźniak J., Krasowska H., ŁaWrynowicz M. (1973): Flora przełomu Warty koło Częstochowy. Rocznik Muzeum w Częstochowie 3: 35-80.

JARzombKowski F., Kozub Ł. (2011): Stan zagrożenia i ochrony mechowisk w krajobrazie rolniczym Mazowsza. In: W. Dembek, A. Gutkowski, H. Piórkowski (eds). Współczesne narzędzia identyfikacji oraz ochrony mokradeł i muraw w krajobrazie rolniczym. Instytut Technologiczno-Przyrodniczy, Zakład Ochrony Przyrody i Krajobrazu Wiejskiego, Falenty: 85-105.

JASNOWSKA J., JASNOWSKI M. (1983): Pojezierze Zachodniopomorskie. Wyd. Wiedza Powszechna, Warszawa.

Jasnowska J., Jasnowski M., Friedrich S. (1993): Badania geobotaniczne w Dolinie Rurzycy na Równinie Wałeckiej. Cz. 2. Wykaz flory grzybów i mszaków w Dolinie Rurzycy. Zeszyty Naukowe Akademii Rolniczej w Szczecinie 155, Rolnictwo, Ser. Przyrodnicza 54: 25-44.

JASNOWski M. (1962): Budowa i roślinność torfowisk Pomorza Szczecińskiego. STN, Wydział Nauk Przyrodniczo-Rolniczych 10. 
JASNOWSKI M. (1990): Torfowiska województwa słupskiego. Stan, zasoby, znaczenie, zasady gospodarowania, ochrona. AR Szczecin, Wojewódzkie Biuro Planowania Przestrzennego w Słupsku, Szczecin.

KarczMARz K. (1960): Mchy okolic Lublina. Fragmenta Floristica et Geobotanica 6(4): 573-592.

Karczmarz K. (1967): Wątrobowce Roztocza. Annales Universitatis Mariae Curie-Skłodowska, Sectio C Biologia 22: 289-327.

Karczmarz K. (1987): Flora mszaków Beskidu Niskiego. Annales Universitatis Mariae Curie-Skłodowska, Sectio C Biologia 42(10): 111-135.

KLAMA H. (2002): Distribution patterns of liverworts (Marchantiopsida) in natural forest communities (Białowieża Primeval Forest, NE Poland). University of Bielsko-Biała, Bielsko-Biała.

Klama H. (2006): Red list of the liverworts and hornworts in Poland. Czerwona lista wątrobowców i glewików w Polsce. In: Z. Mirek, K. Zarzycki, W. Wojewoda, Z. Szeląg (eds). Red list of plants and fungi in Poland. Czerwona lista roślin i grzybów Polski. W. Szafer Institute of Botany, Polish Academy of Sciences, Kraków: 21-33.

Klama H. (2008): A contribution to the liverwort flora of the Tatra National Park (southern Poland). In: A. Stebel, R. Ochyra (eds). Bryophytes of the Polish Carpathians. Sorus, Poznań: 179-183.

KLINGGRAEFF H. (1893): Die Leber- und Laubmoose West- und Ostpreussens. Wilhelm Engelmann, Leipzig.

Koczun A. (2006): Importance of vegetation in the Orawsko-Nowotarskie peat bogs to biological diversity in the Polish Carpathians. Acta Agrophysica 7(2): 383-393.

KoŁA W. (1969): Nowe stanowiska rzadszych wątrobowców w Polsce południowo-zachodniej. Fragmenta Floristica et Geobotanica 15(3): 359-362.

Koppe F. (1929): Zweiter Beitrag zur Moosflora der Grenzmärk Posen-Westpreussen. Abhandlungen und Berichte der Naturwissenschaftlichen Abteilung der Grenzmärkischen Gesellschaft zur Erforschung und Pflege der Heimat (e.V.), Schneidemühl. 4: 5-62.

Kuc M. (1958): Projekt rezerwatu na Górze Kamień z punktu widzenia biologicznego. Chrońmy Przyrodę Ojczystą 14(3): 30-31.

Kuc M. (1959): Mchy Wyżyny Sandomiersko-Opatowskiej (Okręg Sandomierski). Fragmenta Floristica et Geobotanica 5(1): 129-150.

Kuc M. (1963): Materiały briologiczne z Roztocza. Fragmenta Floristica et Geobotanica 9(1): 97-115.

Kuc M. (1964): Briogeografia wyżyn południowych Polski. Monographiae Botanicae 17: 1-211.

LiLIENFELdówna F. (1914): Przyczynek do znajomości krajowych wątrobowców. Sprawozdanie Komisyi Fizyograficznej, Akademia Umiejętności w Krakowie 48: 59-63.
Lisowski S. (1959): Materiały do brioflory Tatr. Prace Komisji Biologicznej Poznańskiego Towarzystwa Przyjaciół Nauk 21(2): 1-128.

Lisowski S., Melosik I., Toвolski K. (2000): Mchy Par$\mathrm{ku}$ Narodowego Bory Tucholskie. Wyd. Homini, Bydgoszcz-Poznań.

MamczARz H. (1973): Mszaki rezerwatu krajobrazowego Czartowe Pole. Annales Universitatis Mariae Curie-Skłodowska, Sectio C Biologia 28: 167-172.

MierzeńsKa M. (2000): Wątrobowce (Hepaticae) Magurskiego Parku Narodowego. In: A. Zając, M. Zając, B. Zemanek (eds). Plan ochrony Magurskiego Parku Narodowego. Magurski Park Narodowy, Krempna: 1-17.

MierzeńsKa M. (2001): Nowe stanowisko rzadkiego wątrobowca Pallavicinia lyellii (Hepaticae, Metzgeriales) w Polsce. Fragmenta Floristica et Geobotanica Polonica 8: 293-295.

MÜlLER K. (1912-1916): Die Lebermoose: Deutschlands, Oesterreichs und der Schweiz mit Berücksichtigung der übrigen Länder Europas. Part 2. In: L. Rabenhorst (ed.). Kryptogamen Flora von Deutschland, Österreich und der Schweiz. Vol. 6, Eduard Kummer, Leipzig.

Ochyra R. (1976): Materiały do brioflory południowej Polski. Zeszyty Naukowe Uniwersytetu Jagiellońskiego 432, Prace Botaniczne 4: 114.

Ochyra R. (1983): Mszaki synantropijne. Wiadomości Botaniczne 27(1): 31-34.

Ochyra R. (1984): Mchy Skalic Nowotarskich i Spiskich (Pieniński Pas Skałkowy). Fragmenta Floristica et Geobotanica 28(3), 1982: 419-489.

Ochyra R., Bednarek-Ochyra H. (1990): Musci Poloniae Exsiccati ab Instituto Botanico Academiae Scientiarum Polonae editi et distributi*. Centuria XII. Nr 1101-1200. [17 unnumbered pp.]. Cracoviae.

Ochyra R., Сүкоwsкa B. (2008): The liverwort flora of the Skalice Nowotarskie and Spiskie Klippen (Polish Western Carpathians). In: A. Stebel, R. Ochyra (eds). Bryophytes of the Polish Carpathians. Sorus, Poznań: 143-167.

Ochyra R., Stebel A. (2008): Mosses of the Małe Pieniny Range (Polish Western Carpathians). In: A. Stebel, R. Ochyra (eds). Bryophytes of the Polish Carpathians. Sorus, Poznań: 74-141.

Ochyra R., Szmajda P., Bednarek H., Bocheński W. (1988 a): M. 484. Helodium blandowii (Web. \& Mohr) Warnst. In: Z. Tobolewski, T. Wojterski (eds). Atlas of the geographical distribution of spore plants in Poland. Vol. 3. Series V. Mosses (Musci). W. Szafer Institute of Botany, Polish Academy of Sciences, Państwowe Wydawnictwo Naukowe, Warszawa-Poznań: 27-33.

Ochyra R., Szmajda P., Bednarek H., Bocheński W. (1988 b): M. 539. Tomentypnum nitens (Hedw.) Limpr. In: Z. Tobolewski, T. Wojterski (eds). Atlas of the geographical distribution of spore plants in 
Poland. Vol. 3. Series V. Mosses (Musci). W. Szafer Institute of Botany, Polish Academy of Sciences, Państwowe Wydawnictwo Naukowe, WarszawaPoznań: 53-61.

Ochyra R., Szmajda P., Bocheński W., Karczmarz K. (1988 c): M. 439. Hedwigia ciliata (Hedw.) P. Beauv. In: Z. Tobolewski, T. Wojterski (eds). Atlas of the geographical distribution of spore plants in Poland. Vol. 4. Series. V. Mosses (Musci). Committee of Botany and Institute of Botany of Polish Academy of Sciences, Warszawa-Poznań: 19-26.

Peciar V. (1978): Studia bryofloristica Slovaciae IX. Acta Facultatis Rerum Naturalium Universitatis Comenianae, Botanica 26: 43-52.

RosadZiŃsKi S., RusiŃSKA A. (2010): Rzadkie i zagrożone wątrobowce polskiej części Dolnych Łużyc. In: A. Szczepkowski, A. Obidziński (eds). Streszczenia referatów i plakatów 55 Zjazdu PTB, Planta in vivo, in vitro et in silico. Warszawa, 6-12 września 2010: 18; Acta Societatis Botanicorum Poloniae 79, supl. 1: 24.

Schumacker R., Martiny P. (1995): Threatened bryophytes in Europe including Macaronesia. In: Red data book of European bryophytes. Part 2. The European Commitee for Conservation of Bryophytes, Trondheim: 29-193.

ŠMARDA J. (1961): Příspěvky k rozšíření jatrovek v Československu. VI. Biologické práce (Bratislava) VII/1: 5-45.

Smith A.J.E. (2004): The moss flora of Britain and Ireland. Cambridge University Press, Cambridge, UK.

Stebel A. (1997): Mszaki Rybnickiego Okręgu Węglowego. Fragmenta Floristica et Geobotanica Series Polonica 4: 121-233.

Stebel A. (2000): Mszaki projektowanego rezerwatu „Las Dąbrowa” na Wyżynie Śląskiej. Natura Silesiae Superioris 4: 57-66.

Stebel A. (2005): Mszaki północno-wschodniej części Kotliny Raciborskiej (Nizina Śląska). Natura Silesiae Superioris 8: 15-37.

Stebel A. (2006): The mosses of the Beskidy Zachodnie as a paradigm of biological and environmental changes in the flora of the Polish Western Carpathians. Śląski Uniwersytet Medyczny and Wydawnictwo Sorus, Katowice-Poznań.

Stebel A. (2008): Materiały do rozmieszczenia chronionych i rzadkich gatunków mszaków na Śląsku Opolskim. Natura Silesiae Superioris 11: 11-25.

Stebel A. (2009 a): Flora mszaków rezerwatu przyrody „Ochojec” na Wyżynie Śląskiej oraz jej przemiany w ciągu ostatnich 10 lat. In: J.B. Parusel (ed.). Rezerwat przyrody „Ochojec” w Katowicach (Górny Śląsk). Monografia naukowo-dydaktyczna. Centrum Dziedzictwa Przyrody Górnego Sląska w Katowicach, Katowice: 110-120.

Stebel A. (2009 b): Mech pędzliczek szerokolistny Syntrichia latifolia (Hartm.) Huebener w Karpa- tach polskich i problemy jego ochrony. Chrońmy Przyrodę Ojczystą 65(4): 293-298.

Stebel A. (2010): Wpływ zbiorników zaporowych na Dunajcu w Pieninach na florę mchów tego regionu. In: R. Soja, S. Knutelski, J. Bodziarczyk (eds). Pieniny - zapora - zmiany. Pieniński Park Narodowy, Krościenko nad Dunajcem: 161-171.

Stebel A., Ochyra R. (2000): Flora mchów Magurskiego Parku Narodowego w Beskidzie Niskim (Karpaty Zachodnie). Fragmenta Floristica et Geobotanica Polonica 7: 229-263.

Stebel A., Ochyra R., Vončina G. (2010): Mosses of the Pieniny Range (Polish Western Carpathians). Sorus, Poznań.

Stebel A., Rosadziński S., Górski P., Fojcik B., Rusińska A., Vončina G., Szczepański M., Wilhelm M., Fudali E., Paciorek T., Staniaszek-Kik M., Zubel R., Piwowarski B., Wolski G., Salachna A., Smolińska D., PierścińsKa A. (2013): Contribution to the bryoflora of the Świętokrzyski National Park (Central Poland). Roczniki Akademii Rolniczej w Poznaniu 392, Botanika-Steciana 17: 77-84.

Szafran B. (1957): Mchy (Musci). Tom I. Flora Polska. Rośliny zarodnikowe Polski i ziem ościennych. Państwowe Wydawnictwo Naukowe, Warszawa.

Szmajda P., Bednarek-Ochyra H., Ochyra R. (1991): M. 295. Splachnum ampullaceum Hedw. In: R. Ochyra, P. Szmajda (eds). Atlas of the geographical distribution of spore plants in Poland. Vol. 7. Series. V. Mosses (Musci). W. Szafer Institute of Botany, Polish Academy of Sciences and Adam Mickiewicz University, Kraków-Poznań: 37-42.

Szweykowski J. (1953): Mszaki Gór Stołowych. Prace Komisji Biologicznej Polskiego Towarzystwa Przyjaciół Nauk 14(5): 1-136.

SzWEYKOWSKI J. (1956): Ważniejsze znaleziska wątrobowców w latach 1955 i 1956. Sprawozdania Poznańskiego Towarzystwa Przyjaciół Nauk, Poznań 46: 118-119.

SzWEYKowsKi J. (1957): Wątrobowce okolic Zwierzyńca nad Wieprzem (pow. Zamość, woj. lubelskie). Fragmenta Floristica et Geobotanica 3(1): 115-126.

Szweykowski J. (1958): Prodromus florae Hepaticarum Poloniae. Prace Komisji Biologicznej Poznańskiego Towarzystwa Przyjaciół Nauk 19.

SzweYKowski J. (1960): Materiały do flory wątrobowców Tatr. Prace Komisji Biologicznej Poznańskiego Towarzystwa Przyjaciół Nauk 21(3): 3-92.

SzWEYKowski J. (1966): H. 65. Trichocolea tomentella (Ehrh.) Dum. In: Z. Czubiński, J. Szweykowski (eds). Atlas of geographical distribution of spore plants in Poland. Vol. 3. Series IV. Polska Akademia Nauk, Poznańskie Towarzystwo Przyjaciół Nauk, Poznań.

SzWEYKowsKi J. (1967): H. 78. Orthocaulis atlanticus (Kaalaas) Buch. In: Z. Czubiński, J. Szweykowski (eds). Atlas of geographical distribution of spore 
plants in Poland. Vol. 4. Series IV. Liverworts (Hepaticae). Polska Akademia Nauk, Poznańskie Towarzystwo Przyjaciół Nauk, Poznań.

SzWEYKOWSKI J. (1969): H. 213. Nowellia curvifolia (Dicks.) Mitten In: J. Szweykowski, T. Wojterski (eds). Atlas of geographical distribution of spore plants in Poland. Vol. 6. Series IV. Liverworts (Hepaticae). Polska Akademia Nauk, Poznańskie Towarzystwo Przyjaciół Nauk, Poznań.

SzWEYKOWSKI J. (2006): An annotated checklist of Polish liverworts and hornworts. - Krytyczna lista wątrobowców i glewików Polski. Biodiversity of Poland. Vol. 4. W. Szafer Institute of Botany, Polish Academy of Sciences, Kraków.

SzWEYKowski J., Buczkowska K. (2000): Sphagnum-Polytrichum hummocks - a bryologically neglected plant formation. Fragmenta Floristica et Geobotanica 45: 475-484.

VÁŇA J. (1969): Jungermannia karl-muelleri Grolle eine neue Art der tschechoslowakischen und karpatischen Bryoflora. Preslia 41: 113-118.

WaCŁAWSKA Z. (1964): Mchy południowej części Niecki Nidziańskiej. Fragmenta Floristica et Geobotanica 10(3): 357-397.

WARNSTORF C. (1906): Kryptogamenflora der Mark Brandenburg und Angrenzenden Gebiete. Bd. II Laubmoose, Verlag von Gebrüder Borntraeger, Leipzig: 1-1160 (I-XII).

Wierzcholska S., Plášek V., Krzysztofiak A. (2010): Mszaki (Bryophyta). In: L. Krzysztofiak (ed.). Śluzowce Myxomycetes, grzyby Fungi i mszaki Bryophyta Wigierskiego Parku Narodowego. Stowarzyszenie „Człowiek i Przyroda”, Suwałki: 229-298.
WiLCZYŃSKA W. (1974): Flora mchów i zbiorowisk mszaków Gór Kaczawskich. Studium florystyczno-ekologiczne. Monographiae Botanicae 44: 3-111.

WinKELMANN J. (1893): Die Moosflora der Umgegend von Stettin. Programm des Schiller-Realgymnasimus zu Stettin 151: 1. F. Hessenland, Stettin.

Wiśniewski T., Rejment I. (1935): Das montane Element in der Lebermoosflora des Seengebietes von Suwałki. Bulletin de l'Académie Polonaise des Sciences et des Lettres, Série B (I): 11-31.

Wojtuń B. (2006): Peat mosses (Sphagnaceae) in mires of the Sudetes Mountains (SW Poland): a floristic and ecological study. University of Agriculture, Wrocław, Poland.

Wolski G. (2011): Stanowiska inwazyjnych gatunków mchów w mieście Łodzi. Acta Botanica Silesiaca 7: 245-250.

Żarnowiec J., Stebel A., Ochyra R. (2004): Threatened moss species in the Polish Carpathians in the light of a new Red list of mosses in Poland. In: A. Stebel, R. Ochyra (eds). Bryological studies in the Western Carpathians. Sorus, Poznań: 9-28.

For citation (1): GóRski P., Pawlikowski P., StaniasZek-KIK M., Rosadziński S., Stebel A., RusińsKa A., Zubel R., Wilhelm M., Fudali E., Cykowska-MaRZencka B., PrzewoźNik L. (2014): New distributional data on bryophytes of Poland, 1. Steciana 18(2): 77-87.

For citation (2): STANIASZEK-KIK M. (2014): 19. Splachnum ampullaceum Hedw. In: P. Górski, A. Stebel, A. Rusińska (eds). New distributional data on bryophytes of Poland, 1. Steciana 18(2): 82. 